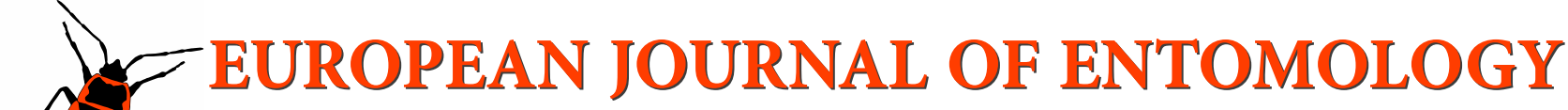 \\ ISSN (online): 1802-8829 \\ http://www.eje.cz \\ Eur. J. Entomol. 115: 504-511, 2018 \\ doi: 10.14411/eje.2018.050 \\ ORIGINAL ARTICLE
}

\section{Does Hartigiola annulipes (Diptera: Cecidomyiidae) distribute its galls randomly?}

\author{
Sebastian PILICHOWSKI ${ }^{1}$ and Marian J. GIERTYCH ${ }^{1,2}$ \\ ${ }^{1}$ University of Zielona Góra, Faculty of Biological Sciences, Prof. Z. Szafrana Str. 1, Zielona Góra 65-516, Poland; \\ e-mail: s.pilichowski@wnb.uz.zgora.pl \\ ${ }^{2}$ Polish Academy of Sciences, Institute of Dendrology, Parkowa Str. 5, 62-035 Kórnik, Poland; e-mail: giertych@man.poznan.pl
}

Key words. Diptera, Cecidomyiidae, Hartigiola annulipes, gall midge, gall distribution, leaf zones, specific leaf area, cardinal directions

\begin{abstract}
It is expected that environmental conditions impact the distribution of galls on host plants. Moreover, insects may induce their galls randomly or choose certain parts of a host to induce such growths. This study aimed to determine whether or not the gall midge, Hartigiola annulipes (Diptera: Cecidomyiidae), which induces galls on leaves of the European beech (Fagus sylvatica), prefers leaves facing a particular cardinal direction. In addition, we wanted to ascertain whether the galls are evenly spread across three leaf zones: proximal, median and distal, distinguished by dividing leaf area along the midrib. The results show that $H$. annulipes chose leaves facing various directions in different studied locations, and leaf choice is not restricted to the specific leaf area, a parameter that accurately reflects the light conditions of leaf growth. Moreover, the medial leaf zone was preferred, while the distal zone was avoided. The choice of the leaf zone modified the distance between the mid-rib and a gall. Gall distribution in the crown of trees is probably random, while at the leaf level, it is determined by leaf morphology.
\end{abstract}

\section{INTRODUCTION}

The search for factors influencing the distribution of insect galls within the crowns of trees and on plant organs has led to several hypotheses suggesting that herbivores choose plant modules to feed on depending on the vigour or size of these modules. One of the most popular is the Plant Vigor Hypothesis (PVH) (Price, 1991), which claims that herbivores choose the most vigorously growing modules to feed on. It appears that the distribution of the eastern spruce adelgid (Adelges abietis Linnaeus) reflects $\mathrm{PVH}$, but small galls develop on lateral shoots of Norway spruce (Picea abies (L.) H. Karst.) and large galls on main shoots (Pilichowski et al., 2014). The main shoots of spruce are usually larger than lateral shoots, but there are fewer of them, thereby limiting the available space for galls. The aphid Kaltenbachiella japonica Matsumura galls the most vigorously growing region of a leaf (Aoyama et al., 2012). Gall-inducers may depend on high vigour and reduce it at the same time by deforming or hindering the growth and development of infested modules (Mendel et al., 2004; Cuevas-Reyes et al., 2008; Urban, 2010).

In addition to different hypotheses (such as PVH, optimal module size hypothesis - OMSH), it is suggested that different abiotic factors may affect gall development, survival and oviposition behaviour, due to their direct effect on a gall-inducer or plant host. Among these factors, insolation, which is associated with the cardinal direction, should be mentioned. East-facing shoots of $P$. abies may be preferred by $A$. abietis; however, this pattern can differ between years (Pilichowski et al., 2014). South-facing galls of the asexual generation of Cynips quercusfolii Linnaeus, on Quercus infectoria G. Olivier, are the largest when compared with other directions (Zargaran et al., 2011). Mikiola fagi Hartig prefers sites within a tree crown that are most exposed to the sun (Kampichler \& Teschner, 2002; Skrzypczyńska \& Lorenc, 2005), while Hartigiola annulipes Hartig prefers shaded sites (Skrzypczyńska \& Lorenc, 2005; Wrzesińska 2012). Both species develop their galls on the adaxial surface of leaves of the European beech (Fagus sylvatica L.). Galls exposed to the sun are thicker, and thus suffer fewer parasitoid attacks (Zargaran et al., 2011).

Determining the degree of insolation of leaves at the time and location of a gall when the eggs are laid is often impossible. Therefore, it is useful to use the specific leaf area (SLA) to estimate light conditions, which is a simple and very useful factor calculated as the ratio between leaf area and dry mass. The analysis of SLA indicates differences in the light conditions in which plants grow (Fellner et al., 2016; Konôpka et al., 2016), thus allowing a comparison between plants of different leaf quality (thickness) and of leaves facing different cardinal directions. Intensity of herbivory increases with SLA (Poorter et al., 2004; Par- 
thasarathy \& Anil, 2016). This may vary, however, with successional stage, and the outcome might be that food availability, not quality, determines herbivory (Poorter et al., 2004). Generally, SLA (and other morphological leaf traits) values are associated with herbivory and fungal damage, which effect the growth rates of trees (Schuldt et al., 2017). Thus, it is worth taking SLA into consideration when studying the distribution of galls on leaves.

Previous studies on the distribution of galls relative to light conditions and/or cardinal directions are mainly at the tree crown level (Kampichler \& Teschner, 2002; Skrzypczyńska \& Lorenc, 2005; Wrzesińska, 2012; Pilichowski et al., 2014).

In this study, we aimed to evaluate the preference of $H$. annulipes (Cecidomyiidae) to gall leaves facing a particular cardinal direction and determine what factors (location, leaf zone, leaf blade area, number of galls) influence the distribution of galls on leaves. Based on the results of previous studies we hypothesized that (1) light conditions for leaf growth (expressed as SLA) will affect the distribution of galls in the crowns of trees, with a preference for galling shaded leaves (high SLA), (2) H. annulipes avoids southfacing leaves, those that receive the most sunlight, and (3) $H$. annulipes prefers to gall the proximal zone of a leaf.

\section{MATERIALS AND METHODS}

Beech gall midges, Hartigiola annulipes Hartig (Cecidomyiidae), produce one generation each year and spend most of their life within single-chambered, hairy galls that develop on leaves of European beech (Fagus sylvatica L.) (Rohfritsch, 1971). The galls detach from the leaves during late summer and early autumn and overwinter in the leaf litter. Imagines emerge from galls in spring, and after mating, females lay eggs on the bottom side of leaves at the beginning of May (Rohfritsch, 1971). In this study, the number of galls counted on leaves included galls that failed to develop and survive, galls that matured and detach from the leaves, and galls still attached to leaves. The purpose was to study the preferences of $H$. annulipes for inducing galls on different parts of a leaf. Whether the galls successfully matured was not measured in this study. Due to the possible effect of microclimatic conditions on the distribution of galls at tree crown and leaf levels, the locations chosen for this study were different types of forests. Leaves collected were free of signs of herbivory and pathogens as far as it was possible to determine with the naked eye.

This study is based on two sets of data, the first was used to determine preferences for galling leaves facing particular cardinal directions and for an initial study of the distribution of galls on these leaves. The second was used to model the relationship between the factors affecting the distribution of galls on leaves. The permission to collect leaves in nature reserves was provided by the Regional Directorate for Environmental Protection in Gorzów Wielkopolski, Poland (document ID: WPN-1-6205.28.2015.AI). To better interpret the results, each location was assigned a label (two beech forests: BF-01 and BF-02 - both are nature reserves, two Scots Pine forests: PF-01 and PF-02 - both are forestry managed forests, one park: P-01 and one urban forest: UF-01) (Table $1)$.

\section{Distribution: cardinal directions and the preliminary study of the distribution of galls on leaves}

To determine whether there is a preference for galling leaves facing a particular cardinal direction, three thousand leaves were randomly collected in October 2015 from three locations in western Poland (Table 1).

At each location (BF-01, BF-02 and PF-01), one thousand leaves (with and without galls) were gathered from five randomly chosen beech trees (several years old) growing in the understory: 200 leaves per tree and 50 per cardinal direction (N, S, E, W). The maximum height at which the leaves were collected was 2 $\mathrm{m}$. Galls of $H$. annulipes were counted in three zones on the leaf lamina: proximal, medial and distal. Each zone was determined by dividing the leaf perpendicularly to the midrib. The proximal zone was defined as the zone at the base of the leaf (Appendix 1).

To determine whether there were differences in the quality of leaves facing each of the four cardinal directions, their specific leaf areas (SLA $\left[\mathrm{cm}^{2} / \mathrm{g}\right]$ ) were determined as follows: 100 leaves were collected from five understory beech trees during late summer, including 20 per tree and 5 per cardinal direction $(\mathrm{N}, \mathrm{S}, \mathrm{E}$, $\mathrm{W})$ in each stand. The leaves were scanned using an Epson Perfection V700 scanner (Seiko Epson Corporation). The images were processed in Image J software version 1.48 by Wayne Rasband, National Institutes of Health, USA, to determine leaf areas. Then, the leaves were oven-dried $\left(60^{\circ} \mathrm{C}\right.$, two days) and weighed using an OHAUS Corp. Adventurer Pro scale Model AV2102CM with $\mathrm{d}=0.01$ grams (precision of scale division).

Table 1. Description of study sites included in the two data sets, with the numbers of trees chosen for collecting leaves and the numbers of leaves collected at each location.

\begin{tabular}{|c|c|c|c|c|c|}
\hline Location & Symbol & Coordinates & Characteristics of the location & No. of leaves & No. of trees \\
\hline \multicolumn{6}{|c|}{ Data set I } \\
\hline "Bukowa Góra" reserve & BF-01 & $\begin{array}{l}51^{\circ} 52^{\prime} 17^{\prime \prime} \mathrm{N} \\
15^{\circ} 44^{\prime} 25^{\prime \prime} \mathrm{E}\end{array}$ & $\begin{array}{l}\text { Natural beech forest located on a hill } \\
\text { near the Odra river (Bobrowniki in Otyń community) }\end{array}$ & 200 & 5 \\
\hline $\begin{array}{l}\text { "Nad Jeziorem Trześ- } \\
\text { niowskim" (NJT) reserve }\end{array}$ & BF-02 & $\begin{array}{l}52^{\circ} 20^{\prime} 41^{\prime \prime N} \\
15^{\circ} 17^{\prime} 22^{\prime \prime} \mathrm{E}\end{array}$ & $\begin{array}{l}\text { Natural beech forest at the Trześniowskie } \\
\text { (Ciecz) Lake in Łagów }\end{array}$ & 200 & 5 \\
\hline $\begin{array}{l}\text { Stary Kisielin district in } \\
\text { Zielona Góra }\end{array}$ & PF-01 & $\begin{array}{l}51^{\circ} 55^{\prime} 55^{\prime \prime} \mathrm{N} \\
15^{\circ} 34^{\prime} 25^{\prime \prime} \mathrm{E}\end{array}$ & $\begin{array}{l}\text { Cultivated Scots pine (Pinus sylvestris L.) forest ( } 57 \text { years } \\
\text { old) in which young beech trees occur in the understory }\end{array}$ & 200 & 5 \\
\hline \multicolumn{6}{|c|}{ Data set II } \\
\hline "Bukowa Góra" reserve & BF-01 & $\begin{array}{l}51^{\circ} 52^{\prime} 17^{\prime \prime} \mathrm{N} \\
15^{\circ} 44^{\prime} 25^{\prime \prime} \mathrm{E}\end{array}$ & $\begin{array}{c}\text { Natural beech forest located on a hill } \\
\text { near the Odra river (Bobrowniki in Otyń community) }\end{array}$ & 265 & 5 \\
\hline Nowy Kisielin & P-01 & $\begin{array}{l}51^{\circ} 55^{\prime} 51^{\prime \prime} \mathrm{N} \\
15^{\circ} 36^{\prime} 46^{\prime \prime} \mathrm{E}\end{array}$ & $\begin{array}{l}\text { A park with a mixed canopy, consisting } \\
\text { of mainly broad-leaved trees }\end{array}$ & 110 & 1 \\
\hline Słupsk & UF-01 & $\begin{array}{l}54^{\circ} 27^{\prime} 12^{\prime \prime} \mathrm{N} \\
17^{\circ} 02^{\prime} 28^{\prime \prime} \mathrm{E}\end{array}$ & Mixed, urban forest in Słupsk & 263 & 5 \\
\hline Zielona Góra & PF-02 & $\begin{array}{l}51^{\circ} 53^{\prime} 58^{\prime \prime} \mathrm{N} \\
15^{\circ} 29^{\prime} 22^{\prime \prime} \mathrm{E}\end{array}$ & $\begin{array}{l}\text { Cultivated Scots pine forest near Dzika Ochla pond } \\
\text { in Zielona Góra }\end{array}$ & 454 & 5 \\
\hline
\end{tabular}




\section{(BF-01)}

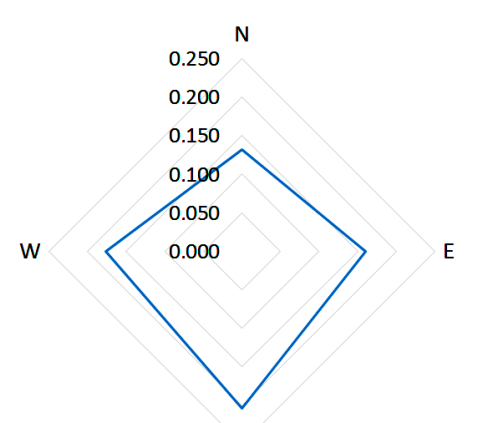

s

$p=0.0022$

(BF-02)

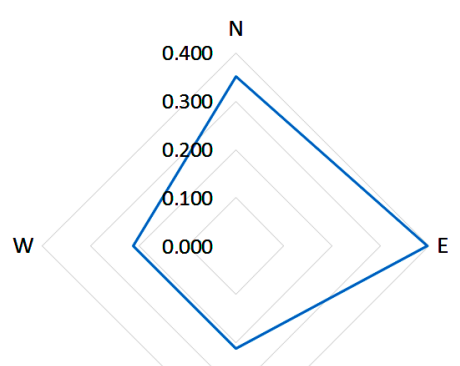

s $p<0.0001$

(PF-01)

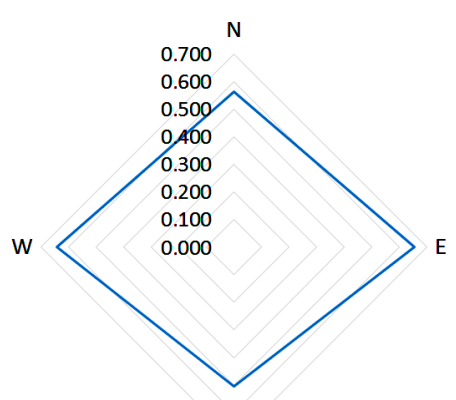

S

$p<0.0001$

Fig. 1. Radar charts based on $\chi^{2}$ tests, presenting frequency of occurrence of $H$. annulipes galls on leaves facing each of the four cardinal directions (N, E, W, S) at each study site. BF-01 ("Bukowa Góra" reserve) and BF-02 ("Nad Jeziorem Trześniowskim" reserve) are natural beech forests. PF-01 (Stary Kisielin - Zielona Góra) - a managed Scots pine forest with beech trees occurring in the understory. Probabilities shown in each chart represent $p$ values obtained from the $\chi^{2}$ tests.

\section{Distribution of galls on leaves - a model}

To determine the frequency of occurrence of the galls on different parts of a leaf, 1092 leaves of the common beech, each bearing at least one gall of $H$. annulipes, were collected at four locations (BF-01, P-01, UF-01, PF-02) in Poland from trees growing in the understory (up to $3 \mathrm{~m}$ tall) between September and October 2015 (Table 1). Locations of the material collected differed in terms of type of forest, which is expected to be an important factor affecting the results. The number of leaves collected at each location was different due to differences in the availability of beech trees, abundance of galled leaves and forest management. In the park in Nowy Kisielin (P-01), there was only a single European beech tree growing in the understory sufficient for material

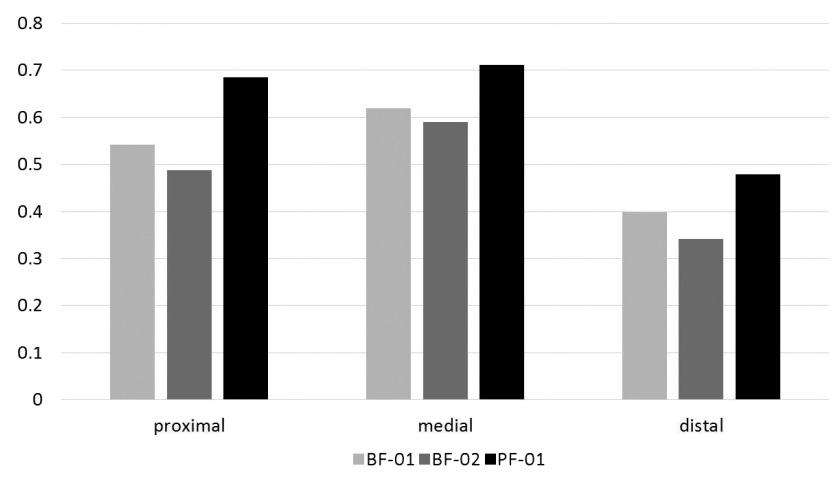

Fig. 2. Differences in the frequency of the occurrence of galls in different leaf zones at three study sites based on a contingency analysis $\left(\chi^{2}\right)$. Differences between locations were significant (BF01: $p=0.0002$, BF-02 and PF-01: $p<0.0001$ ). BF-01 ("Bukowa Góra" reserve) and BF-02 ("Nad Jeziorem Trześniowskim" reserve) are natural beech forests. PF-01 (Stary Kisielin - Zielona Góra) - a managed Scots pine forest with beech trees occurring in the understory.

collection, while five trees were chosen for collection at the other three locations. In Zielona Góra (PF-02), the infestation level was very high, and thus, the number of leaves collected there was the highest.

The area $\left[\mathrm{mm}^{2}\right]$ and length $[\mathrm{mm}]$ along the midrib of each leaf was measured using ImageJ software. ImageJ was also used to measure the perpendicular distance of $H$. annulipes galls from the midrib [mm]. The total number of $H$. annulipes galls was recorded.

\section{Statistical analyses}

The $\chi^{2}$ test was used to check differences between the presence and absence of galls in each leaf zone, as well as the preference for particular cardinal directions (data set 1). An ANOVA was used to estimate the effect of individual beech trees, cardinal direction and interaction on SLA. One gall was randomly chosen out of 1092 galls for each leaf analyzed. We used log-transformed values of the distance between the midrib and galls to normalize the distribution of the data. Then, a linear mixed model (LMM) was used to determine the effect of the factors (leaf zone, leaf blade area, number of galls, location and number of beech trees) on the distance between the midrib and galls (dependent variable) (data set 2). The numbers of beech trees and locations were treated as random factors and beech trees were nested in the locations (the script is shown in Appendix 2).

Statistical analyses were performed using JMP PRO 13 software (SAS Institute Inc., Cary, NC, USA).

\section{RESULTS}

Hartigiola annulipes galls were very common as they were found on more than $35 \%$ of beech leaves. A total of $4512 H$. annulipes galls were recorded on 3000 leaves. The abundance of galls differed at the different locations. Most galls (3375) were found at PF-01; and 655 and 482 were recorded in the nature reserves BF-02 and BF-01, respectively. Of the collected leaves, 1949 were not galled and 346 had only one gall. The highest number of galls per leaf was 76 (in PF-01). The numbers of galls and galled leaves are shown in Appendix 3.

The $\chi^{2}$ analysis of gall presence ( 0 or 1$)$ and the cardinal direction revealed different frequencies at each location studied, which are presented in the form of a radar chart 
Table 2. ANOVA results of relationships between specific leaf area (SLA) of beech leaves and the following three factors: individual beech tree, cardinal direction and interaction. Abbreviations: DF - degrees of freedom, DFE - degrees of freedom for error, $F$ - result of the F-test, $p$ - probability.

\begin{tabular}{lcccc}
\hline Source of variation & DF & DFE & F & $p$ \\
\hline Location & 2 & 12 & 1.5877 & 0.2445 \\
Tree (Location) & 12 & & & \\
Cardinal direction & 3 & 36 & 1.7374 & 0.1767 \\
Location x Cardinal Direction & 6 & 36 & 0.5550 & 0.7628 \\
Cardinal direction (Tree(Location)) & 36 & & & \\
Residual & 240 & & & \\
\hline
\end{tabular}

(Fig. 1). At BF-01, H. annulipes preferred south-facing and avoided north-facing leaves $\left(\chi_{(3, \mathrm{~N}=3000)}^{2}=14.595, p=\right.$ 0.0022). At BF-02, they preferred east-facing leaves and strongly avoided west- and south-facing leaves $\left(\chi_{(3, N=3000)}^{2}\right.$ $=98.522, p<0.0001)$. At PF-01, the insects mainly galled east- and west-facing leaves, while avoiding south-facing ones $\left(\chi_{(3, \mathrm{~N}=3000)}^{2}=44.696, p<0.0001\right)$.

The presence of galls in different leaf zones differed significantly at each location (BF-01: $p=0.0002$, BF-02 reserve and PF-01: $p<0.0001)$. The medial zone was galled the most, while the distal zone was avoided (Fig. 2).

The influences of location, cardinal direction and interaction factors on the SLA were not significant (Table 2).

The distance between the mid-rib and galls was significantly associated with two factors: leaf blade area and leaf zone (Table 3). The distance between the mid-rib and galls increases with leaf area, and the distance between the mid-rib and galls in the distal zone was shorter than in the proximal zone $(p<0.0001)$. The analyses were done for the proximal zone. The model equation obtained was $\mathrm{Y}=$ $0.3273-0.2334 \mathrm{DZ}+0.0002 \mathrm{~A}$, where $(\mathrm{Y})$ was the distance between the mid-rib and galls, (DZ) was the distal leaf zone and (A) was the leaf area.

\section{DISCUSSION}

Our results show that $H$. annulipes chooses leaves facing different cardinal directions. Skrzypczyńska \& Lorenc (2005) and Wrzesińska (2012) claim that $H$. annulipes galls are more common on shaded leaves. The amount of light available for plants in a forest depends on the type and age of the forest (Peters, 1997; Guo et al., 2017) and differs in forests composed of conifers and broad-leaved species (which may shed their leaves seasonally) due to variations in the densities of their canopies, species of trees present, their growth rates and requirements. Older trees, which are usually taller than those growing in the understory, as well as fast growing individuals, compete more efficiently for light than smaller or slow-growing trees (Peters, 1997; Kobayashi et al., 2000; Schulte et al., 2013). These facts may be an important issue affecting the results of this study since the trees studied were growing in the understory of different types of forest. However, since gall midges are considered to be poor flyers (Urban, 2000), studies of gall distribution in mature tree crowns may be pointless. In contrast, Kampichler \& Teschner (2002) do not agree that gall midges are poor flyers. The overstory tree species
Table 3. Linear mixed model relating distance between the mid-rib and galls on different parts of a leaf (zone), leaf area and number of $H$. annulipes galls. Model includes locations and trees nested in location as random effects. SE - standard error.

\begin{tabular}{lrlr}
\hline Term & Estimate & SE & \multicolumn{1}{c}{$p$} \\
\hline Intercept & 0.3273 & 0.0911 & 0.0157 \\
Zone [distal] & -0.2334 & 0.0453 & $<0.0001$ \\
Zone [medial] & 0.0616 & 0.0356 & 0.0840 \\
Leaf area & 0.0002 & 0.00002 & $<0.0001$ \\
Number of galls & 0.0010 & 0.0041 & 0.8030 \\
\hline
\end{tabular}

composition in forests may influence the amount of light reaching the understory when the leaves are mature (Sercu et al., 2017); moreover, natural and managed forests with different species compositions may influence understory plants differently (Thomsen et al., 2005), and various types of managed forests influence the biodiversity (Gao et al., 2014). These findings indicate it is likely that the stands studied differed in terms of environmental conditions (e.g., light transmittance), which may have influenced the preferences for leaves facing in particular directions.

There were no differences in SLA, which was assumed to be an indirect measure of light conditions. The expectation was that SLA would be important in determining preferences for leaves facing different directions since there are reports of relationships between SLA and herbivory (Poorter et al., 2004; Parthasarathy \& Anil, 2016). The results presented do not support the first hypothesis that SLA depends on the direction that leaves face. At BF-01, the galls were mainly on south-facing leaves and north-facing leaves were avoided. At the BF-02 reserve, where there is a natural beech forest by a lake, and at PF-01, where we collected leaves from understory trees growing in a managed conifer forest, the first leaves to be galled were eastfacing (which are the first leaves to be exposed to sun in the morning). The comparison of the frequency of $H$. annulipes galls at BF-02 and PF-01 indicates that even though insects prefer east-facing leaves, environmental conditions modify preferences towards other cardinal directions. By environmental conditions, we specifically mean microclimatic differences (abiotic factor) between beech and pine forests and the availability of trees for infestation (biotic factor). At BF-02, where leaves were collected from beeches growing on the western side of a lake, the east-facing leaves may receive more solar radiation due to openings in the canopy and distribution of the trees. However, at PF01, a managed pine forest with a few beech trees, similar preferences were recorded for west- and east-facing leaves. It seems that in this case, $H$. annulipes is more opportunistic and uses the resources randomly. It is likely that females choose oviposition sites based on the abundance of food rather than its quality (vigour). Statistical analyses indicated no influence of the factors studied on SLA. Even though the trees chosen for SLA analyses were solitary and in the understory (not in contact with other trees) in order to avoid the effect of shading, it was not possible to determine the effect of cardinal direction on leaf quality (expressed as SLA). These results led to the assumption that 
the light conditions were similar in each of the four main cardinal directions.

We could not find any evidence in the literature that females of $H$. annulipes were attracted to light, which could account for their oviposition behaviour. Do females become active in the morning after sunrise and lay their eggs on young, east-facing leaves? We speculate that they do, and later during the day, they may randomly lay their eggs on leaves, due to an increase in the activity of the insects in response to rising temperatures during the day. Skrzypczyńska \& Lorenc (2005) and Wrzesińska (2012), who claim that $H$. annulipes galls were more common on shaded leaves, did not support this thesis with a statistical analyses, and the aim of their studies was not to determine the preferences of $H$. annulipes. Yukawa et al. (1988) show that Mycophila sp. (Cecidomyiidae) exhibits phototaxis. Similar conclusions come from the study of Dasineura oxycoccana Johnson (Cecidomyiidae) by Roubos \& Liburd (2010) as it has the same preference for light and a southerly direction, whereas females of Stenodiplosis sorghicola Coquillett (Cecidomyiidae) are colour- and odour-attracted (Sharma \& Franzmann, 2001). If females of H. annulipes show the same pattern of behaviour, they may also react to the different light wavelengths reflected by or passing through young leaves during the day according to the position of the sun. The optical properties of leaves and bark of common beech change during the plant's lifetime (Pilarski et al., 2008). Leite et al. (2011) report that an unidentified galling species belonging to the Eurytomidae (Hymenoptera) prefers the middle zones of Caryocar brasiliense Camb. north-facing leaflets. The positioning of galls may be strongly influenced by inter-specific competition within a tree crown (Leite et al., 2011), with fungal endophytes being a threat to the survival of gall insects (Wilson \& Carroll, 1997) and leaf-miners (Wilson \& Faeth, 2001), or as McGeoch \& Price (2004) show, positioning may be weakly affected by inter-specific competition. For $H$. annulipes, such a competitor may be Mikiola fagi Hartig (Diptera: Cecidomyiidae), which also galls the leaves of $F$. sylvatica. Nonetheless, M. fagi galls were absent at PF-01, while they occur at BF-01 and BF-02, but $H$. annulipes galls were by far the most abundant (personal observation). Thus, a comparison of distributions of the galls of both species occurring in the areas studied is difficult. This raises a need for further studies. Aphidoletes aphidimyza Rondani (Cecidomyiidae), a predatory gall midge, does not avoid ovipositing at sites already occupied by conspecific females and their eggs (Kohandani et al., 2017). Females of $A$. aphidimyza tend to clutch their eggs at a single oviposition site (Kohandani et al., 2017). Perhaps females react to a site that is acceptable for other females as an optimal site. However, intraspecific competition cannot be avoided, as the food resources for larvae are limited. This would account for the occurrence of $76 \mathrm{H}$. annulipes galls on a single leaf (Appendix 3) at PF-01, where beech trees are rare.

Food resources and natural enemies are the most important biotic factors influencing the success and survival of herbivores (Whitham, 1978; Kaplan et al., 2014) along with host plant phenology (Urban, 2000; Aoyama et al., 2012). In addition, ontogeny and microclimatic conditions modify the degree of herbivory (Stiegel \& MantillaContreras, 2018). Since galling animals are specialists, it is expected that they are favoured or limited by these two factors. Hence, galls should occur in a place where it can be well-supplied by the host plant and where the risk of predation or parasitism is low. Furthermore, the cardinal direction in which a leaf faces and on which galls are located could determine the likelihood of it being attacked by herbivores, predators (Evans \& Gregoire, 2006) and/or parasitoids (Zargaran et al., 2011). In contrast, some studies indicate no preference in the occurrence of galls facing any of the four cardinal directions, e.g., Forda riccobonii Stefani (Hemiptera: Pemphigidae) forming galls on the Pistacia atlantic Desf. (Martinez, 2009). The random distribution of galls according to cardinal directions minimizes parasitoid attacks at some sites since there are studies indicating that light conditions may modify the behaviour of parasitoid wasps (Luo \& Chen 2016; Cochard et al., 2017; Kelch et al., 2017). Consequently, such a distribution of galls might be considered as a trade-off between avoiding parasitoids and occupying the most beneficial galling sites.

Moreover, there are reports that herbivores prefer particular parts of plants. Various chemical compounds protect plants against herbivores and pathogens. For example, phenolic compounds, the quantities and concentrations of which differ in different plant species and their parts (Abrahamson et al., 2003; Oliveira Ribeiro et al., 2014). Furthermore, they change seasonally (Bernal et al., 2013; Oliveira Ribeiro et al., 2014) and with age (Bhakta \& Ganjewala, 2009) and may be influenced by environmental factors (Estiarte et al., 1994; Loponen et al., 2001; Borges et al., 2013). Petrakis et al. (2011) report phenols in the leaves and bark of F. sylvatica in Greece and that infested beech leaves have higher concentrations of total phenolic compounds and that it increases with the number of insects attacking beech trees. The concentration of phenolics in host organs can vary, which affects the distribution of galls (Zucker, 1982; Bergvinson, 1997; Giertych \& Karolewski, 2000; Gutterman \& Chauser-Volfson, 2000; Ferreira et al., 2014). Thus, we expected that $H$. annulipes would avoid galling the distal zone and prefer the proximal third of leaves. Indeed, the results show that the frequency of galls occurring in the distal zone (Fig. 2) is the lowest when compared to the median and proximal zones. However, they also show that $H$. annulipes slightly prefers the median zone to the proximal zone of leaves, but only in natural beech forests. In the managed Scots pine forest, with a few beech trees in the understory (PF-01), the frequency of galling of the proximal and median zone is much lower. This may be due to the rarity of the host plant, which results in a high number of galls per leaf, the highest recorded number of $H$. annulipes galls on one leaf in PF-01 reached 76 (Appendix 3), while in the BF-01 and BF-02 reserves, it reached 20 and 12, respectively (Appendix 3 ). 
The position of a gall on a leaf may also be important if the distance from the midrib is taken into consideration. The LMM model incorporates only two significant factors (zone of occurrence and leaf area) that influence the distance between a gall and the midrib. Relative to the proximal zone, the distance of a gall in the distal zone is significantly shorter, and galls that developed on the largest leaves tend to be further from the mid-rib. These results correspond with the obvious presumptions that as the distal zone narrows towards the tip, galls have to develop closer to the mid-rib, which also becomes thinner than in the proximal zone. There is still too little knowledge about the distributional patterns of galls on leaves. Giertych et al. (2013) report that leaf size and distance from the petiole to the gall (C. quercusfolii) are positively correlated, but they did not discuss the results for the distance of the gall to the midrib as they were not significant. Leite et al. (2011) show that the central parts of C. brasiliense leaflets are more frequently galled than the borders and midrib. We suppose that large leaves allow the establishment of galls further from the mid-rib than small leaves, because a larger area and thicker lateral veins provide galls and larvae with enough resources to ensure their growth and development. Furthermore, galls may not be affected by the high concentrations of harmful secondary metabolites flowing in the mid-rib. In this way, $H$. annulipes can optimize the location of its galls. Stiegel \& Mantilla-Contreras (2018) studied herbivory rates of common beech at three different heights. The authors assume that it is impossible to establish a herbivory-pattern for a single species. Instead, they propose to study such patterns at the guild level.

It must be mentioned that the material used in this study was collected from understory trees, and thus, the results may be limited to explaining the distributional pattern of galls of $H$. annulipes on young trees. If this gall-midge is sensitive to concentrations of various chemical compounds, especially secondary metabolites, then it may respond with different distributional patterns at different heights and in different parts of the canopy. Dudt \& Shure (1994) report that the shade-tolerant plant, Cornus florida, L. contains more phenolics than shade-intolerant Liriodendron tulipifera L. F. sylvatica is also considered to be a shade-tolerant species, and Stiegel et al. (2017) suggest that the high carbon content of $F$. sylvatica leaves in upper canopies reflect high concentrations of phenols. Numerous studies report a connection between the chemical quality of leaves and light availability (Crone \& Jones, 1999; Roberts \& Paul, 2006; Oliveira Ribeiro et al., 2014), with shaded leaves having high concentrations of phenols (Dudt \& Shure, 1994); however, the latter is not a general rule, as proven by Karolewski et al. (2013) and suggested by Stiegel et al. (2017) in the case of F. sylvatica.

\section{CONCLUSIONS}

This study shows that Hartigiola annulipes galls the leaves of common beech randomly at the crown level and leaves facing different cardinal directions.
H. annulipes exhibits some preference for inducing galls on east-facing leaves and tends to avoid south-facing leaves.

$H$. annulipes prefers to induce galls in the medial zone of a leaf and avoids the distal zone.

SLA values did not explain the distribution of galls on leaves.

The choice of leaf zone can influence the distance between a gall and the mid-rib.

ACKNOWLEDGEMENTS. The research was supported by the National Science Centre of Poland (Narodowe Centrum Nauki) research grant 2013/11/N/NZ9/00106 (Hartigiola annulipes and Mikiola fagi and their galls occurring on common beech leaves (Fagus sylvatica) - influence on host, distribution ecology and parasitism).

\section{REFERENCES}

Abrahamson W.G., Hunter M.D., Melika G. \& Price P.W. 2003: Cynipid gall-wasp communities correlate with oak chemistry. -J. Chem. Ecol. 29: 209-223.

Aoyama T., Shin-IChi A. \& Hasegawa E. 2012: Gall distribution as a compromise between the optimal gall-site selection and the synchrony to host-plant phenology in the aphid Kaltenbachiella japonica. - Arthr.-Plant Interact. 6: 461-469.

BERGVINSON D.J. 1997: Windows of maize resistance. Insect resistant maize: Recent advances and utilization. In Mihm J.A. (ed.): Proceedings of an International Symposium held at the International Maize and Wheat Improvement Center (CIMMYT) 27 November - 3 December, 1994. CIMMYT, Mexico, pp. 117-126.

Bernal M., Llorens L., Julkunen-Tittto R., Badosa J. \& VerDAGUER D. 2013: Altitudinal and seasonal changes of phenolic compounds in Buxus sempervirens leaves and cuticles. Plant Physiol. Biochem. 70: 471-482.

Bhakta D. \& Ganjewala D. 2009: Effect of leaf positions on total phenolics, flavonoids and proanthocyanidins content and antioxidant activities in Lantana camara (L). - J. Sci. Res. 1: 363-369.

Borges L.L., Alves S.F., Sampaio B.L., Conceição E.C., Bara M.T.F. \& PAULA J.R. 2013: Environmental factors affecting the concentration of phenolic compounds in Myrcia tomentosa leaves. - Revta Bras. Farmacogn. 23: 230-238.

Cochard P., Galstian T. \& Cloutier C. 2017: Light environments differently affect parasitoid wasps and their hosts' locomotor activity. - J. Insect Behav. 30: 595-611.

Crone E.E. \& Jones C.G. 1999: The dynamics of carbon-nutrient balance: Effects of Cottonwood acclimation to short- and longterm shade on beetle feeding preferences. - J. Chem. Ecol. 25: 635-656.

Cuevas-Reyes P., Quesada M. \& Oyama K. 2008: Abundance and leaf damage caused by gall-inducing insects in a mexican tropical dry forest. - Biotropica 38: 107-115.

DudT J.F. \& ShuRE D.J. 1994: The influence of light and nutrients on foliar phenolics and insect herbivory. - Ecology 75: 86-98.

Estiarte M., Filella I., Serra J. \& Peñuelas J. 1994: Effects of nutrient and water stress on leaf phenolic content of peppers and susceptibility to generalist herbivore Helicoverpa armigera (Hubner). - Oecologia 99: 387-391.

Evans A.M. \& Gregoire T.G. 2006: The tree crown distribution of hemlock woolly adelgid, Adelges tsugae (Hem., Adelgidae) from randomized branch sampling. - J. Appl. Entomol. 131: 26-33. 
Fellner H., Dirnberger G.F. \& Sterba H. 2016: Specific leaf area of European Larch (Larix decidua Mill.). — Trees 30: $1237-1244$

Ferreira R.O., de Carvalho A.R., da Silva T.M.G., Castro R.N., DA Silva T.M.S. \& De Carvalho M.G. 2014: Distribution of metabolites in galled and non-galled leaves of Clusia lanceolata and its antioxidant activity. - Revta Bras. Farmacogn. 24: 617-625.

Gao T., Hedblom M., Emilsson T. \& Nielsen A.B. 2014: The role of forest stand structure as biodiversity indicator. - Forest Ecol. Manag. 330: 82-93.

Giertych M.J. \& KarolewsKi P. 2000: Phenolic compounds distribution along the lenght of Scots pine needles in a polluted and control environment and its connection with necroses formation. - Acta Soc. Bot. Polon. 69: 127-130.

GierTych M.J., JaGodziński A.M. \& Karolewski P. 2013: Spatial distribution of Cynips quercusfolii (Hymenoptera: Cynipidae) galls on leaves and within the crowns of oak trees. - Eur. J. Entomol. 110: 657-661.

Guo Q., Chi X., XIE Z. \& TAng Z. 2017: Asymmetric competition for light varies across functional groups. - J. Plant Ecol. 10 74-80.

Gutterman Y. \& Chauser-Volfson E. 2000: The distribution of the phenolic metabolites barbaloin, aloeresin and aloenin as a peripheral defense strategy in the succulent leaf parts of Aloe arborescens. - Biochem. Syst. Ecol. 28: 825-838.

Kampichler C. \& Teschner M. 2002: The spatial distribution of leaf galls of Mikiola fagi (Diptera: Cecidomyiidae) and Neuroterus quercusbaccarum (Hymenoptera: Cynipidae) in the canopy of a Central European mixed forest. - Eur. J. Entomol. 99: 79-84.

Kaplan I., McArt S.H. \& Thaler J.S. 2014: Plant defenses and predation risk differentially shape patterns of consumption, growth, and digestive efficiency in a guild of leaf-chewing insects. - PLOS ONE 9(4): e93714, 8 pp.

Karolewski P., GierTych M.J., ŻMUda M., JAGodZińsKi A.M. \& OLEKSYN J. 2013: Season and light affect constitutive defenses of understory shrub species against folivorous insects. - Acta Oecol. 53: 19-32.

Kelch N.S., Neves F.S., Fernandes G.W. \& Wirth R. 2017: Mechanisms driving galling success in a fragmented landscape: synergy of habitat and top-down factors along temperate forest edges. - PLOS ONE 11(6): e 0157448, $17 \mathrm{pp}$.

Kobayashi T., Muraoka H. \& Shimano K. 2000: Photosynthesis and biomass allocation of beech (Fagus crenata) and dwarfbamboo (Sasa kurilensis) in response to contrasting light regimes in a Japan sea-type beech forest. - J. Forest Res. 5: 103-107.

Kohandani F., Le Goff G.J. \& Hance T. 2017: Does insect mother know under what conditions it will make their offspring live? - Insect Sci. 24: 141-149.

KonôpKa B., Pajtík J., MarušÁK R., Bošel'a M. \& LuKac M. 2016: Specific leaf area and leaf area index in developing stands of Fagus sylvatica L. and Picea abies Karst. - Forest Ecol. Manag. 364: 52-59.

Leite G.L.D., Cerqueira V.M., D’Avila V.A., Magalhaes C.H.P. \& Fernandes G.W. 2011: Distribution of a leaf vein gall in Caryocar brasiliense (Caryocaraceae) tree. - Revta Caatinga 24: 186-190.

Loponen J., Lempa K., Ossipov V., Kozlov M.V., Girs A., Hangasmaa K., Haukioja E. \& Pihlaja K. 2001: Patterns in content of phenolic compounds in leaves of mountain birches along a strong pollution gradient. - Chemosphere 45: 291-301.

Luo C.W. \& CHen Y. 2016: Phototactic behavior of Scleroderma guani (Hymenoptera: Bethylidae) - parasitoid of Pissodes punctatus (Coleoptera: Curculionidae). - J. Insect Behav. 29: 605-614.

MARTINEZ J.J. 2009: Population ecology of Forda riccobonii (Hemiptera: Pemphigidae) on Pistacia atlantica. — Orient. Insects 43: $241-251$.

McGeoch M.A. \& Price P.W. 2004: Spatial abundance structures in an assemblage of gall-forming sawflies. - J. Anim. Ecol. 73: 506-516.

Mendel Z., Protasov A., Fisher N. \& La Salle J. 2004: Taxonomy and biology of Leptocybe invasa gen. \& sp. n. (Hymenoptera: Eulophidae), an invasive gall inducer on Eucalyptus. - Austral. J. Entomol. 43: 101-113.

Oliveira Ribeiro A., Goulart S., Mori F. \& Fonseca Castro A. 2014: Tree crown variation and seasonal in the phenolic compounds content of Stryphnodendron adstringens (Mart) Coville leaves. - Am. J. Plant Sci. 5: 2904-2912.

Parthasarathy N. \& Anil K. 2016: Leaf traits and foliar herbivory in tropical dry evergreen forest of India. - Trop. Plant Res. 3: 52-66.

Peters R. 1997: Chapter 5: Growth and form: beech versus other dominant tree species. In Peters R.: Beech Forests. Springer, Dordrecht, pp. 58-88.

Petrakis P.V., Spanos K., Feest A. \& Daskalakou E. 2011: Phenols in leaves and bark of Fagus sylvatica as determinants of insect occurrences. - Int. J. Mol. Sci. 12: 2769-2782.

Pilarski J., ToKarz K. \& KocureK M. 2008: Optical properties of the cork of stems and trunks of beech (Fagus sylvatica L.). Pol. J. Environ. Stud. 17: 773-779.

Pilichowski S., Pazio D. \& Giertych M.J. 2014: Factors associated with the distribution and size of Adelges abietis (Homoptera: Adelgidae) galls on a several years old spruce (Picea abies) plantation. - Acta Entomol. Fenn. 25: 161-169.

Poorter L., De Plassche M.V., Willems S. \& Boot R.G.A. 2004: Leaf traits and herbivory rates of tropical tree species differing in successional status. - Plant Biol. 6: 746-754.

PrICE P.W. 1991: The plant vigor hypothesis and herbivore attack. - Oikos 62: 244-251.

RoBerts M.R. \& PAUL N.D. 2006: Seduced by the dark side: integrating molecular and ecological perspectives on the influence of light on plant defence against pests and pathogens. - New Phytol. 170: 677-699.

RoHFritsch O. 1971: Developpement Ceciden et rôle du parasite dans quelques galles d'Arthropodes. - Marcelia 37: 233-339.

Roubos C.R. \& LibuRd O.E. 2010: Evaluation of emergence traps for monitoring blueberry gall midge (Diptera: Cecidomyiidae) adults and within field distribution of midge infestation. $-J$. Econ. Entomol. 103: 1258-1267.

Schuldt A., Hönig L., Li Y., Fichtner A., Härdtle W., von Oheimb G., Welk E. \& Bruelheide H. 2017: Herbivore and pathogen effects on tree growth are additive, but mediated by tree diversity and plant traits. - Ecol. Evol. 7: 7462-7474.

Schulte M.J.D., Matyssek R., Gayler S., Priesack E. \& Grams T.E.E. 2013: Mode of competition for light and water amongst juvenile beech and spruce trees under ambient and elevated levels of $\mathrm{O}_{3}$ and $\mathrm{CO}_{2}$. - Trees 27: 1763-1773.

Sercu B.K., Baeten L., van Coillie F., Martel A., Lens L., VerHEYEN K. \& BONTE D. 2017: How tree species identity and diversity affect light transmittance to the understory in mature temperate forests. - Ecol. Evol. 7: 10861-10870.

Sharma H.C. \& Franzmann B.A. 2001: Orientation of sorghum midge, Stenodiplosis sorghicola, females (Diptera: Cecidomyiidae) to color and host-odor stimuli. - J. Agr. Urban Entomol. 18: $237-248$. 
SKRZYPCZYŃSKA M. \& LoRENC M. 2005: [Preliminary study on abundance of galls on beech leaves Fagus sylvatica L. in the Bieszczady National Park.] — Dipteron 21: 32 [in Polish].

Stiegel S. \& Mantilla-Contreras J. 2018: Environment vs. plant ontogeny: Arthropod herbivory patterns on European beech leaves along the vertical gradient of temperate forests in Central Germany. - Insects 9(1): 9, 28 pp.

Stiegel S., Entling M.H. \& Mantilla-Contreras J. 2017: Reading the leaves' palm: Leaf traits and herbivory along the microclimatic gradient of forest layers. - PLOS ONE 12(1): e0169741, 17 pp.

Thomsen R.P., Svenning J.-C. \& Balslev H. 2005: Overstorey control of understorey species composition in a near-natural temperate broadleaved forest in Denmark. - Plant Ecol. 181: $113-126$.

Urban J. 2000: Beech gall midge (Mikiola fagi Htg.) and its natural enemies. - J. Forest Sci. 46: 543-568.

URBAN J. 2010: Occurrence, development and gall polymorphism of Harmandiola cavernosa (Rübs.) (Diptera, Cecidomyiidae). - Acta Univ. Agr. Silvicult. Mendel. Brun. 58: 235-258.

Whitham T.G. 1978: Habitat selection by Pemphigus aphids in response to response limitation and competition. - Ecology 59: 1164-1176.

Wilson D. \& CARroll G.C. 1997: Avoidance of high-endophyte space by gall-forming insects. - Ecology 78: 2153-2163.

WiLSON D. \& FAETH S.H. 2001: Do fungal endophytes result in selection for leafminer ovipositional preference? - Ecology 82: $1097-1111$.

WRZESIŃSKA D. 2012: [Foliophages inducing plant-galls in Fagus sylvatica L.] - Sylwan 156: 843-847 [in Polish].

Yukawa J., Anraku S. \& Haitsuka S. 1988: Phototaxis and movement of a paedogenetic gall midge, Mycophila sp. (Diptera: Cecidomyiidae) infesting the oyster mushroom. - Proc. Assoc. Plant Prot. Kyushu 34: 151-153.

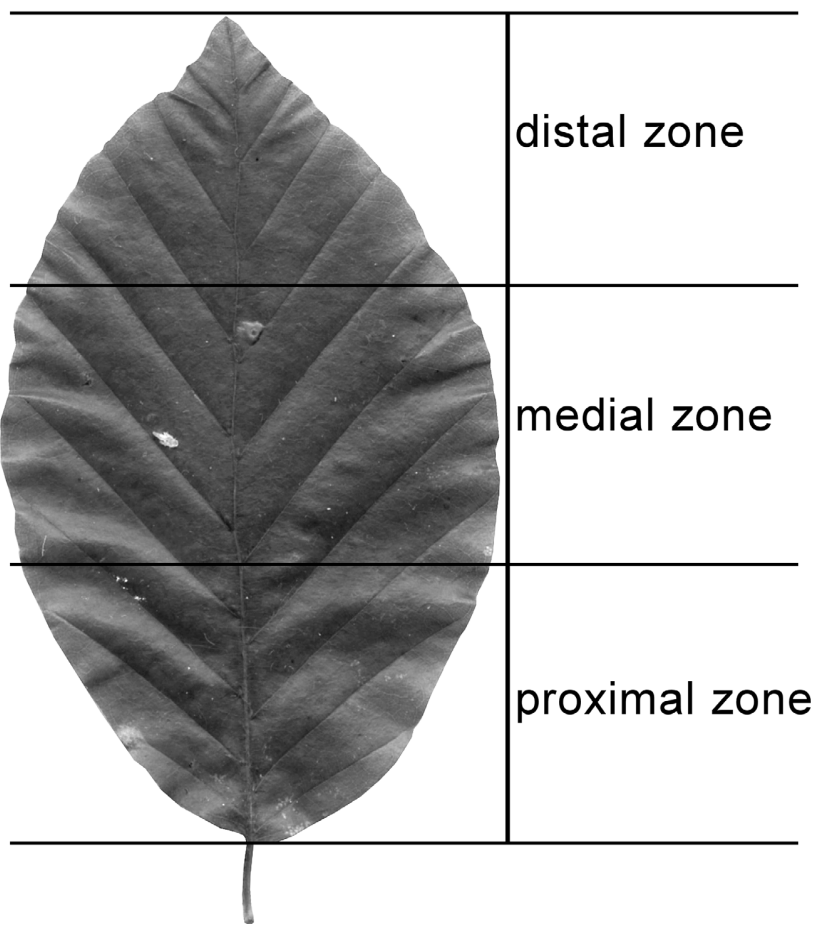

Appendix 1. The figure shows the way the leaf was divided into three zones (proximal, medial and distal) along the mid-rib. Each zone is of equal length along the mid-rib. The proximal zone is the nearest to the petiole.
Zargaran M.R., Safaralizadeh M.H., Pourmirza A.A. \& ValiZADEGAN O. 2011: Effect of cardinal directions on gall morphology and parasitization of the gall wasp, Cynips quercusfolii. - J. Insect Sci. 11: 169, 10 pp.

ZUCKER W.V. 1982: How aphids choose leaves: the roles of phenolics in host selection by a galling aphid. - Ecology 63: 972-981.

Received January 17, 2018; revised and accepted July 15, 2018 Published online September 14, 2018

Appendix 2. The script used in the linear mixed model (LMM). Statistical analyses were performed in the JMP PRO 13 (SAS Institute Inc., Cary, NC, USA).

Fit Model (Y(:Name(" $\log$ [distance between the mid-rib and galls $[\mathrm{mm}]]$ ")),

Effects (:zone, :leaf area, :number of galls),

Random Effects (:location, :tree[:location]),

Personality ("Mixed Model"));

Appendix 3. Number of leaves with a particular number of Hartigiola annulipes galls recorded at each location.

\begin{tabular}{|c|c|c|c|c|}
\hline \multirow[b]{2}{*}{$\begin{array}{l}\text { Number } \\
\text { of galls }\end{array}$} & \multicolumn{3}{|c|}{ Number of leaves at each location } & \multirow[b]{2}{*}{ Total } \\
\hline & $\begin{array}{c}\text { Bukowa } \\
\text { Góra } \\
\text { (BF-01) }\end{array}$ & $\begin{array}{l}\text { Nad Jeziorem } \\
\text { Trześniowskim } \\
\text { (BF-02) }\end{array}$ & $\begin{array}{l}\text { Stary } \\
\text { Kisielin } \\
\text { (PF-01) }\end{array}$ & \\
\hline 0 & 832 & 707 & 410 & 1949 \\
\hline 1 & 66 & 150 & 130 & 346 \\
\hline 2 & 37 & 67 & 103 & 207 \\
\hline 3 & 22 & 25 & 72 & 119 \\
\hline 4 & 16 & 20 & 62 & 98 \\
\hline 5 & 5 & 9 & 40 & 54 \\
\hline 6 & 6 & 7 & 28 & 41 \\
\hline 7 & 4 & 5 & 25 & 34 \\
\hline 8 & 5 & 5 & 25 & 35 \\
\hline 9 & 1 & 1 & 15 & 17 \\
\hline 10 & 2 & 0 & 12 & 14 \\
\hline 11 & 2 & 3 & 11 & 16 \\
\hline 12 & 1 & 1 & 12 & 14 \\
\hline 13 & 0 & 0 & 1 & 1 \\
\hline 14 & 0 & 0 & 7 & 7 \\
\hline 15 & 0 & 0 & 4 & 4 \\
\hline 16 & 0 & 0 & 4 & 4 \\
\hline 17 & 0 & 0 & 4 & 4 \\
\hline 18 & 0 & 0 & 5 & 5 \\
\hline 19 & 0 & 0 & 4 & 4 \\
\hline 20 & 1 & 0 & 2 & 3 \\
\hline 21 & 0 & 0 & 1 & 1 \\
\hline 22 & 0 & 0 & 2 & 2 \\
\hline 23 & 0 & 0 & 2 & 2 \\
\hline 24 & 0 & 0 & 2 & 2 \\
\hline 25 & 0 & 0 & 3 & 3 \\
\hline 26 & 0 & 0 & 2 & 2 \\
\hline 28 & 0 & 0 & 1 & 1 \\
\hline 29 & 0 & 0 & 1 & 1 \\
\hline 30 & 0 & 0 & 1 & 1 \\
\hline 35 & 0 & 0 & 2 & 2 \\
\hline 36 & 0 & 0 & 1 & 1 \\
\hline 37 & 0 & 0 & 1 & 1 \\
\hline 49 & 0 & 0 & 1 & 1 \\
\hline 52 & 0 & 0 & 1 & 1 \\
\hline 54 & 0 & 0 & 1 & 1 \\
\hline 56 & 0 & 0 & 1 & 1 \\
\hline 76 & 0 & 0 & 1 & 1 \\
\hline Total & 1000 & 1000 & 1000 & 3000 \\
\hline
\end{tabular}

